
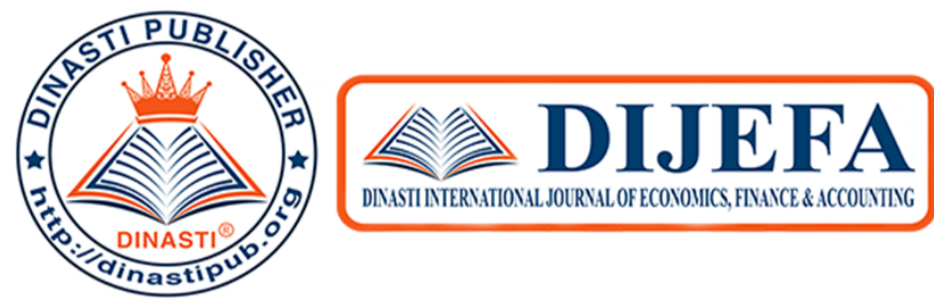
+6281387654578? +6281387654578 (Q) https://dinastipub.org/DIJEFA (-) dinasti-info@gmail.com ↔

\title{
THE EFFECT OF STATEGIC MANAGEMENT ON MANAGERIAL PERFORMANCE WITH STRATEGIC IMPLEMENTATION AS A MODERATING VARIABLES (EMPIRICAL STUDY OF THE PULO GADUNG INDUSTRIAL AREA, JAKARTA)
}

\section{Apollo}

Departemen Accounting, Mercu Buana University Jakarta

\begin{tabular}{|c|c|}
\hline $\begin{array}{l}\text { ARTICLE INFORMATION } \\
\text { Received: } 21 \text { August } 2020 \\
\text { Revised: } 30 \text { August } 2020 \\
\text { Issued: } 24 \text { September } 2020\end{array}$ & 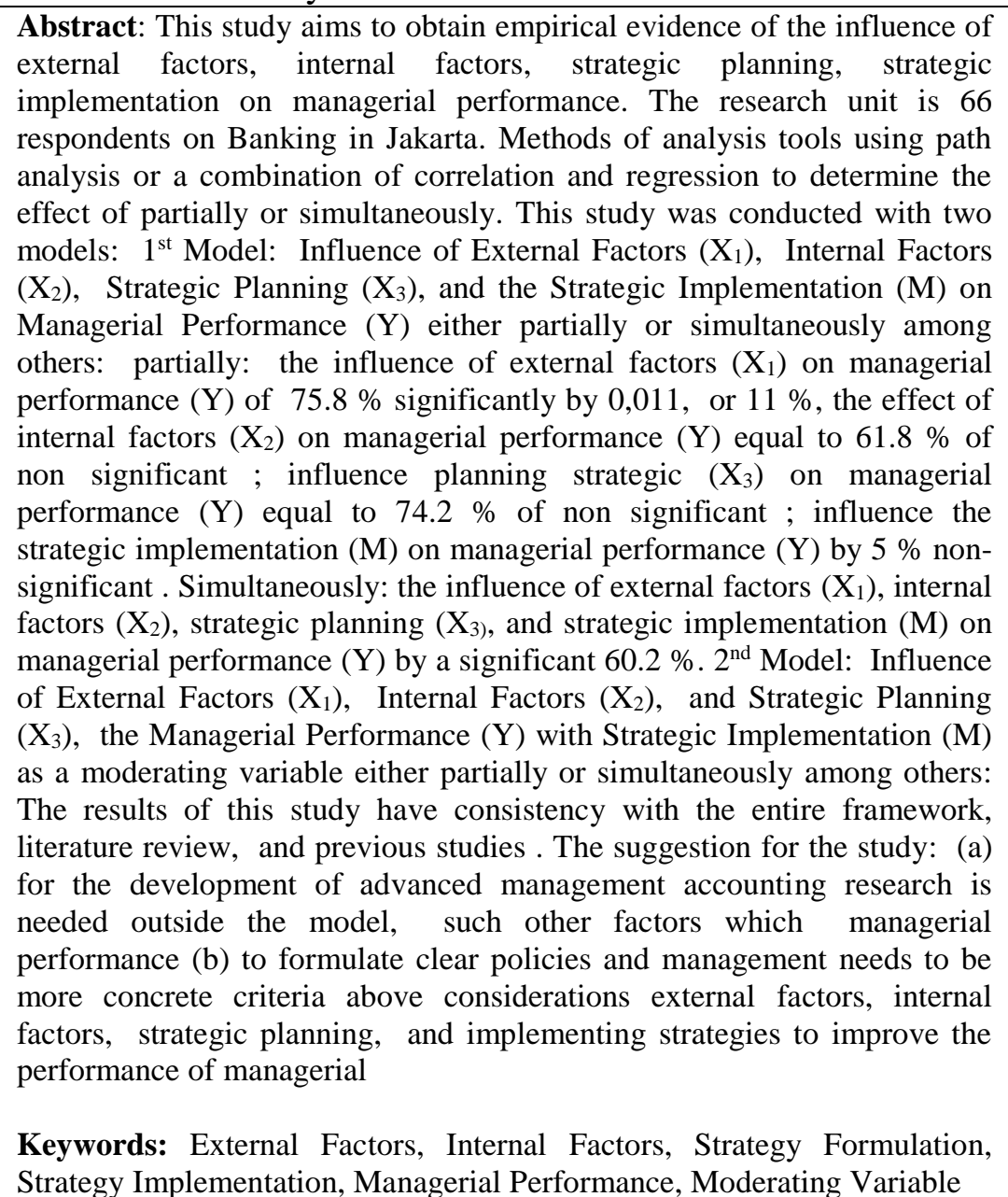 \\
\hline
\end{tabular}

\section{INTRODUCTION}

Managerial performance is an illustration of the level of achievement of the implementation of a strategic plan in realizing goals. As accountability to an organization, managers must inform shareholders and organizational leaders about the level of achievement of results, in relation to the mission and vision of the organization. 
The factors that influence the managerial performance of Whellen and Hunger (2012) are associated with external factors, internal factors, strategic planning, and strategy implementation in Figure 1.

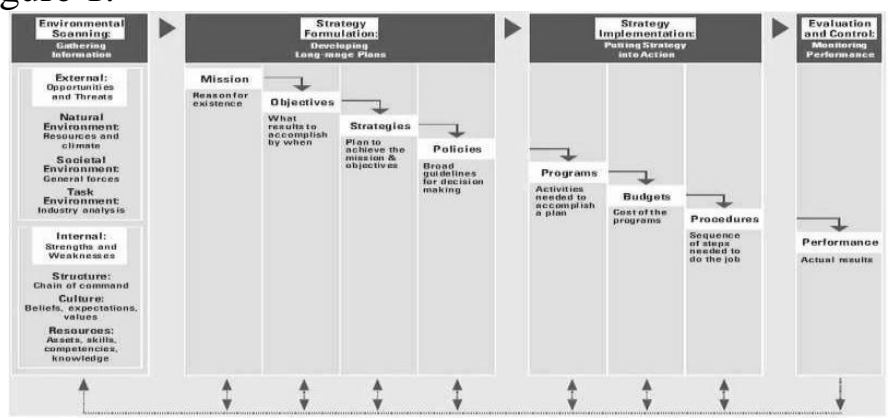

Figure 1. The factors that influence the managerial performance Source Whellen and Hunger (2012)"Strategic Management and Business Policy"

Based on Figure 1, to achieve managerial performance, managers carry out environmental scanning, which includes external and internal factors, then the manager determines the strategy formulation or strategic planning and implements the strategy so that there is performance or managerial performance as evaluation and control.

The phenomenon of strategy failure on managerial performance is influenced by independent variables (external factors, internal factors, strategic planning) and moderating variables (strategic implementation). More specifically, the identification of research problems is formulated or structured as follows: (1) how do external factors, internal factors, strategic planning and strategic implementation influence managerial performance (either partially or simultaneously). (2) how do external factors, internal factors, strategic planning influence managerial performance with strategic implementation as moderating variable (partially or simultaneously).

\section{LITERATURE REVIEW}

Managerial performance has the following indicators: (1) task achievement, (2) employees who meet the requirements, (3) high productivity, (4) individual contributors, (5) work unity with effective and efficient managerial performance, (6) originating from the function of the activity, (7) obeying applicable laws, (8) overall results, (9) as a target or target, (10) something that has been agreed upon. Wood, Wallace, Zeffane (1998), Bernardin and Russell (2002), Whellen and Hunger (2012); Gary Dessler (2008: 290), Gomes (2003: 130).

Wheelen and Hunger (2007: 234) say: "common environmental factors can be classified as follows: a) economic factors, b) social and political factors, c) regulatory factors and the law (legal factors), d) factors of science and technology, and e) demographic factors". The external environment has the following indicators: (1) is outside the organization, (2) cannot be directly controlled by management, (3) has a major influence on performance, (4) identifies impacts, (5) must be aware of it, (6) influential in decision making, (7) includes opportunities (8) includes threats, (9) is general in nature, (10) does not directly affect the organization. Wood et al. (1993), David (2005), Whellen and Hunger (2007: 234);

Wheelen and Hunger (2012: 184): "internal factors have three main parts: (1) organizational structure, (2) organizational learning, and (3) resources". Internal environmental variables have the following indicators: (1) assessing marketing and distribution, (2) assessing 
research and development, (3) assessing production and operations, (4) assessing resources and employees, (5) taking advantage of opportunities and dealing with threats in within the company, (6) related to the nature of a person, (7) the factors contained in the organization itself, (8) focuses on strengths, (9) focuses on weaknesses, (10) aims at marketing, financial, and operational systems. Jauch and Glack (2000: 162), Fred R. David (2009: 47).

Strategic planning has the following indicators: (1) to achieve the best possible goal, (2) maximize the use of resources, (3) determine the goals to be achieved, (4) relate to the company's mission, (5) to develop the business, (6) carried out or arranged by the manager, (7) systematic arrangement of steps to be taken, (8) steps for the future, (9) based on careful consideration, (10) the existence of the SWOT principle. Dovel et al. (1993), Stoner and Freeman (1994), Abe (2001), Sorkin, Ferris, and Hudak (2001: 254), Porter (1980: 57) divides competitive strategy into three types of parts, among others: (1) cost leadership, namely low cost and best value, (2) differentiation, and (3) focus, namely low cost and best value;

The strategic implementation variable has the following indicators: (1) fully dependent on commitment, (2) full responsibility, (3) pressure from a series of steps, (4) strategic actions are carried out carefully, (5) consistent implementation actions, (6) carried out by individuals, (7) to achieve goals, (8) goals based on policy decisions, (9) want to achieve competitiveness, (10) earn above average income. Schermerhorn (1996: 172), Hitt, Ireland, and Hoskisson (2000: 188), Moore (1995: 71), Wheelen and Hunger (2012: 317).

\section{RESEARCH METHODS}

This research is a verification research or aims to clarify the relationship and influence of the variables in testing the hypothesis or it is called explanatory (Zikmund, 1997). This study uses 4 variables to explain managerial performance.

\subsection{Measurement}

Managerial performance is influenced by external factors (X1), internal factors (X2), strategic planning (X3), and strategic implementation (M). In this study, the measurement of indicators was compiled in literature review and previous research journals to be developed in the form of variable operationalization; Table 1 presents the number of dimensions and indicator Table 2 variables, the number of dimensions and indicators equipped with the library sources used; The measurement scale uses five scales from strongly disagree [1] to strongly agree on scale [5]: 
Table 2 Operationalization of Research Variables

\begin{tabular}{|l|l|c|l|}
\hline $\begin{array}{l}\text { Nom } \\
\text { or }\end{array}$ & Variabel & $\begin{array}{l}\text { Indicat } \\
\text { or }\end{array}$ & Literature \\
\hline 1 & $\begin{array}{l}\text { External } \\
\text { Factors }\end{array}$ & 10 & $\begin{array}{l}\text { Wood et al. (1993), David (2005), Whellen, Hunger } \\
(2007: 234) ;\end{array}$ \\
\hline 2 & $\begin{array}{l}\text { Internal } \\
\text { Factors }\end{array}$ & 10 & $\begin{array}{l}\text { Jauch and Glack (2000:162), Fred R. David } \\
(2009: 47), \text { Wheelen Hunger (2012:184) }\end{array}$ \\
\hline 3 & $\begin{array}{l}\text { Strategic } \\
\text { planning }\end{array}$ & 10 & $\begin{array}{l}\text { Moore, J.F. (1995), Stoner, Freeman (1994), Pearce } \\
\text { II, Robinson. (2003), Sorkin, Ferris, Hudak } \\
\text { (2001:254), Porter (1980:57); Porter, (2008). }\end{array}$ \\
\hline 4 & $\begin{array}{l}\text { Strategy } \\
\text { implementation }\end{array}$ & 10 & $\begin{array}{l}\text { Schermerhor (1996:172), Hitt, Ireland, dan } \\
\text { Hoskisson (2000: 188), Moore (1995:71), Whellen, } \\
\text { Hunger (2012:317). }\end{array}$ \\
\hline 5 & $\begin{array}{l}\text { Managerial } \\
\text { Performance }\end{array}$ & 10 & $\begin{array}{l}\text { Wood, Wallace, Zeffane (1998), Bernardin Russell } \\
(2002), \text { Wheelen Hunger (2012); Gary Dessler (2008: } \\
\text { 290), Gomes (2003:130). }\end{array}$ \\
\hline
\end{tabular}

\subsection{Research Data}

This research was conducted at Pulo Gadung Industrial Area, Jakarta Indonesia. The sampling technique using the Slovin model. This research is a quantitative study, includes a general description of the respondents, demographics, then performs statistical analysis to test the hypothesis. To test the hypothesis used multiple regression analysis path analysis model, after testing the validity and reliability, as well as the transformation of ordinal data to intervals;

This research uses multiple regression analysis analysis, first performed the operationalization of the variables, measuring dimensions and indicators, compiling a questionnaire, and testing the normal distribution, and data outliers; in this study the number of samples (n: 104), with five Likert scale;

\section{FINDING AND DISCUSSIONS}

The method of analysis uses multiple regression to determine the effect partially and simultaneously. The results of the research were first tested for validity, reliability, and transformation of ordinal data into intervals.

Table 3 Cronbach's Alpha reliability test criteria $(0.60)$, and product moment validity

(0.202)

\begin{tabular}{|l|l|l|l|}
\hline $\begin{array}{l}\text { Nom } \\
\text { or }\end{array}$ & Variable & $\begin{array}{l}\text { Statistiaka } \\
\text { Cronbach's } \\
\text { Alpha }(0.60)\end{array}$ & $\begin{array}{l}\text { Product } \\
\text { moment }(0.202)\end{array}$ \\
\hline 1 & External Factors & 0.877 & $0.492-0.600$ \\
\hline 2 & Internal Factors & 0.831 & $0.403-0.632$ \\
\hline 3 & Strategic planning & 0.885 & $0.393-0.755$ \\
\hline 4 & Strategy implementation & 0.868 & $0.467-0.652$ \\
\hline 5 & Managerial Performance & 0.854 & $0.447-0.599$ \\
\hline
\end{tabular}

4.1 Model path Analysis 


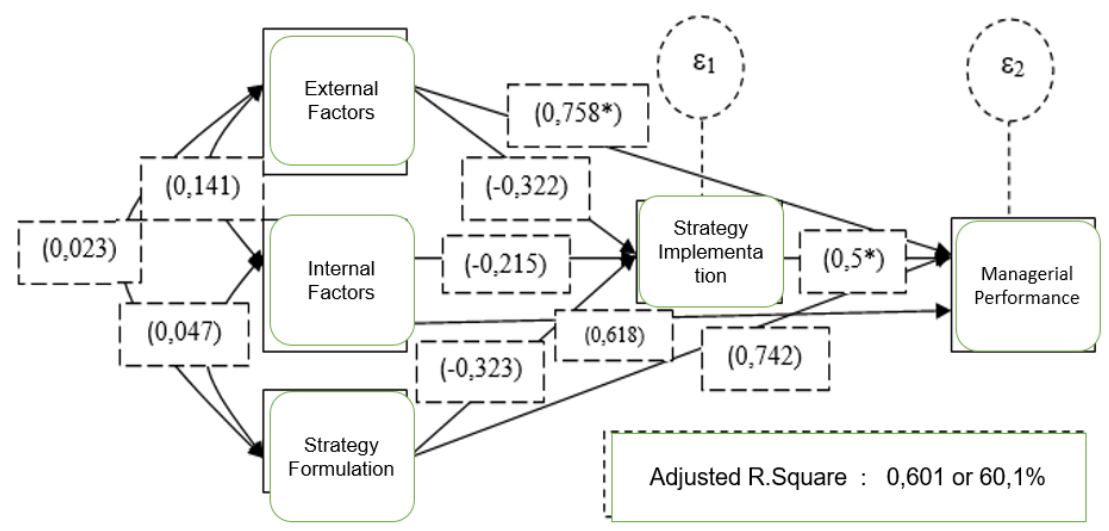

Y

$$
: \beta_{0}+\beta_{1} X_{1}+\beta_{2} X_{2}+\beta_{3} X_{3}+\beta_{4} M+\beta_{5} X_{1} X_{2}+\beta_{6} X_{1} X_{3}+\beta_{7} X_{2} X_{3}+
$$
$\beta_{8} \mathrm{X}_{1} \mathrm{M}+\beta_{9} \mathrm{X}_{2} \mathrm{M}+\beta_{10} \mathrm{X}_{3} \mathrm{M}+\varepsilon$

Y

: $65,851+0,384 \mathrm{X}_{1}+0,062 \mathrm{X}_{2}+0,222 \mathrm{X}_{3}+0,202 \mathrm{M}+0,082 \mathrm{X}_{1} \mathrm{X}_{2}+$

$$
0,144 \mathrm{X}_{1} \mathrm{X}_{3}+0,3 \mathrm{X}_{2} \mathrm{X}_{3}-0,08 \mathrm{X}_{1} \mathrm{M}-0,172 \mathrm{X}_{2} \mathrm{M}-0,226 \mathrm{X}_{3} \mathrm{M}
$$
Parsial Uji (t) :$$
(0,031 *) \quad(0,627)
$$
$(0,202)$
$(0,044 *) \quad(0,706)$

$$
\begin{array}{lllll}
(0,567) & (0,202) & (0,724) & (0,313) & (0,294)
\end{array}
$$

\section{Parsial}

$$
(0,758 *) \quad(0,618)
$$

Simultaneous Test F: $\left(0,000^{*}\right)$

$$
(0,023) \quad(0,047) \quad(-0,322) \quad(-0,215) \quad(-0,323)
$$

Adjusted R.Square : 0,601 atau 60,1\%

Alpha

(*)

$\varepsilon$

Explanation :

Y

$\beta_{0}$

$\beta_{1}, \beta_{2}, \ldots \beta_{4}$

$\mathrm{X}_{1}$

$\mathrm{X}_{2}$

$\mathrm{X}_{3}$

$\mathrm{M}$

$\mathrm{X}_{1} \mathrm{X}_{2}$

$\mathrm{X}_{1} \mathrm{X}_{3}$

$\mathrm{X}_{2} \mathrm{X}_{3}$

$\mathrm{X}_{1} \mathrm{M}$

$\mathrm{X}_{2} \mathrm{M}$

$\mathrm{X}_{3} \mathrm{M}$

implementation
: 0,05

: Significant

: 0,399 atau $39,9 \%$

: Managerial Performance

: constanta $\varepsilon$

: slope coefficients

: external factors

: internal factors,

: strategic planning,

: strategy implementation

: the interaction of external factors and internal factors

: the interaction of external factor variables and strategic planning

: the interaction of internal factor variables and strategic planning

: interaction of external factor variables and strategic implementation

: the interaction of internal factor variables and strategic implementation : the interaction of strategic planning variables and strategic

: error terms

4.2 The Influence of External Factors (X1), Internal Factors (X2), and Strategic Planning (X3), on Managerial Performance (Y) with Strategic Implementation as Partial Moderating Variables 
Table 4. Finding of Research

\begin{tabular}{|c|c|c|c|c|c|c|c|c|c|c|c|c|}
\hline \multirow[b]{2}{*}{ Model II } & \multicolumn{11}{|c|}{ Findings } & \\
\hline & $\mathrm{X}_{1}$ & $\mathrm{X}_{2}$ & $\mathrm{X}_{3}$ & M & $\mathrm{X}_{1} \mathrm{X}_{2}$ & $X_{1} X_{3}$ & $\mathrm{X}_{2} \mathrm{X}_{3}$ & $\mathrm{X}_{1} \mathrm{M}$ & $\mathrm{X}_{2} \mathrm{M}$ & $\mathrm{X}_{3} \mathrm{M}$ & $\begin{array}{l}\text { Adj R } \\
\text { Square }\end{array}$ & \\
\hline \multirow{5}{*}{$\begin{array}{l}\text { The Influence } \\
\text { of External } \\
\text { Factors (X1), } \\
\text { Internal Factors } \\
\text { (X2), and } \\
\text { Strategic } \\
\text { Planning (X3), } \\
\text { on Managerial } \\
\text { Performance } \\
\text { (Y) with } \\
\text { Strategic } \\
\text { Implementation } \\
\text { as Partial } \\
\text { Moderating }\end{array}$} & 0,758 & 0,618 & 0,742 & 0,5 & 0,141 & 0,023 & 0,047 & 0,322 & 0,215 & 0,323 & 0,601 & Influence \\
\hline & $0,031 *$ & 0,627 & 0,202 & $0,044^{*}$ & 0,706 & 0,567 & 0,202 & 0,724 & 0,313 & 0,294 & $0,000 *$ & $\begin{array}{l}(*) \\
\text { signifikan }\end{array}$ \\
\hline & $(+)$ & $(+)$ & $(+)$ & $(+)$ & $(+)$ & $(+)$ & $(+)$ & $(-)$ & $(-)$ & $(-)$ & $(+)$ & Path sign \\
\hline & 66 & 66 & 66 & 66 & 66 & 66 & 66 & 66 & 66 & 66 & 66 & Sampling \\
\hline & 0,05 & 0,05 & 0,05 & 0,05 & 0,05 & 0,05 & 0,05 & 0,05 & 0,05 & 0,05 & 0,05 & Alpha \\
\hline
\end{tabular}

There is a positive influence of external factors (X1), the relationship between everything that lies outside the organization and the organization itself greatly affects managerial performance $(\mathrm{Y})$. If a factor originating from outside the organization is placed in the right position it can further affect managerial performance. The higher the external factors seen, the more managerial performance can be achieved at 0.758 or $75.8 \%$, a significant effect of 0.031 or $31 \%$. This means that every 1 unit increase in the external factor variable, the managerial performance will increase by 0.384 with the assumption that other variables are fixed.

There is a positive influence of internal factors (X2) on managerial performance $(\mathrm{Y})$, the environment within the organization also affects how a manager can manage his employees in order to cooperate with other employees and how well these employees know the organization so that they can master their work. The better the management of internal factors in the organization, the higher the managerial performance in it, which is 0.618 or $61.8 \%$ has no significant effect. This means that every increase in the unit's internal factor variable, the managerial performance will increase by 0.062 with the assumption that other variables are fixed.

There is a positive effect of strategic planning (X3) on managerial performance (Y). By having a strategic plan, a job within the organization can run smoothly, because of the structure. A well-designed strategy will affect future managerial performance. Companies that have planned and designed strategies carefully will form a good managerial performance. The higher the strategic planning, the higher the managerial performance of 0.742 or $74.2 \%$ which has no significant effect. This means that for every increase in the strategic planning variable by 1 unit, the managerial performance will increase by 0.222 with the assumption that other variables are fixed.

There is a positive influence on strategic implementation (M) on managerial performance $(\mathrm{Y})$. With strategic implementation, it means that an organization has carried out or implemented a plan that has been formed by the manager to achieve its goals. Strategy 
implementation is an important factor in improving managerial performance with a welldesigned strategy. If the strategy cannot be implemented effectively, it is useless. The higher the strategic implementation, the higher the managerial performance of 0.5 or $5 \%$ has a significant effect of 0.044 or $44 \%$. This means that every increase in the unit's strategic implementation variable will increase the managerial performance by 0.202 , assuming the other variables are fixed.

The test of the influence of model II on external factors, internal factors, strategic planning, strategic implementation on managerial performance aims to test the effect of the independent variable $(\mathrm{X})$ and the moderating variable $(\mathrm{M})$ together on the dependent variable (Y). The simultaneous effect test usually uses the $\mathrm{F}$ test (ANOVA test).

Based on the results of SPSS 21 output, there is a positive influence between external factors (X1), internal factors (X2), strategic planning (X3), strategic implementation (M) on managerial performance $(\mathrm{Y})$ simultaneously, which is 0.641 or $64.1 \%$ and declared significant at the alpha level of 0.000 .

There is a positive relationship between external factors (X1) and the concept of Wood et al. (1993) analysis of the industry in which there are 4 actions, namely: (1) Identifying the impact, (2) It must be realized, (3) Having a big influence, (4) Influencing decision making with Internal Factors (X2) the concept of Glueck and Jaunch ( 2000) with the dimensions of organizational capabilities, namely: (1) Taking advantage of opportunities, (2) Handling threats, (3) Assessing distribution systems, (4) Assessing operating systems, (5) Assessing resources within the organization, on Managerial Performance $(\mathrm{Y})$ with the dimensions of evaluation (indicators: something achieved, work unity, as a target, high productivity, overall results, activity results), coordination (indicators: meeting requirements, individual contribution, obeying the law, something that has been agreed upon), amounting to 0.141 or $14.1 \%$ and not significant. This means that every 1 unit increase in the external factor variable, the internal factor variable increases by 0.082 , assuming the other variables are constant.

There is a positive relationship between External Factors (X1), the concept of Wood et al. (1993) analysis of the industry which contains 4 actions, namely: (1) Identifying impacts, (2) It must be realized, (3) Having a large influence, (4) Influencing decision making with Strategic Planning (X3) which is formed as a future step. front of the company. With the knowledge in identifying the impact of threats and opportunities from outside the company, managers can form a strategic plan that can be used to improve Managerial Performance (Y with the evaluation dimension (indicator: something achieved, work unity, as a target, productivity). high, the results of the overall, the results of activities), coordination (indicators: meeting the requirements, individual contribution, obeying the law, something that has been agreed upon), amounting to 0.023 or $23 \%$ and insignificant. This means that every increase in the external factor variable is 1 unit then the strategic planning variable will increase by 0.144 assuming the other variables are fixed.

The positive relationship between the Internal Factors (X2) of the concept of Glueck and Jaunch (2000) dimensions of organizational capability, namely: (1) Taking advantage of opportunities, (2) Dealing with threats, (3) Assessing distribution systems, (4) Testing the operating system, (5) Assessing resources and employees with strategic planning (X3) the concept of Tjokroamidjojo (1992) which has a process dimension, namely: (1) Achieving goals, (2) Maximizing resources within the organization, (3) To develop the business, (4) Steps for the future, (5) Goal setting, (6) Related to the mission, (7) Arranged by the manager, (8) Systematic arrangement, on Managerial Performance (Y) with evaluation dimensions 
(indicator: something achieved, work unity, as a target, high productivity, overall results, activity results), coordination (indicators: meeting requirements, individual contribution, law abiding, something that has been agreed upon), amounting to 0.047 or $47 \%$ and insignificant. This means that for each increase in the internal factor variable by 1 unit, the strategic planning variable will increase by 0.3 assuming other variables are fixed.

There is a negative relationship between External Factors (X1), the concept of Wood et al. (1993) analysis of the industry in which there are 4 actions, namely: (1) Identifying impacts, (2) It must be realized, (3) Having a large influence, (4) Influencing decision making with Strategic Implementation (M) Wahab concept (2001) namely: (1) Performed by individuals, (2) To achieve goals, (3) Objectives based on policy decisions, on Managerial Performance (Y) with the evaluation dimension (indicators: something achieved, work unity, as a target, high productivity, overall results, activity results), coordination (indicators: meeting the requirements, individual contribution, obeying the law, something that has been agreed upon), amounting to -0.322 or $32.2 \%$ and not significant. This means that every 1 unit increase in the external factor variable, the strategic implementation variable will decrease by 0.08 units, assuming the other variables are fixed.

There is a negative relationship between Internal Factors (X2) and Strategic Implementation (M), namely between the management of resources within the organization with strategic implementation or implementation of Managerial Performance (Y) with the evaluation dimension (indicators: something achieved, work unity, as target, high productivity, overall results, activity results), coordination (indicators: meeting requirements, individual contribution, obeying the law, something that has been agreed upon), amounting to -0.215 or $21.5 \%$ and not significant. This means that for every increase in the internal factor variable by 1 unit, the strategic implementation variable will decrease by 0.172 units, assuming the other variables are fixed.

There is a negative relationship between Strategic Planning (X3) having a process dimension, namely: (1) Achieving goals, (2) Maximizing existing resources within the organization, (3) To develop business, (4) Steps for the future, (5) ) Goal setting, (6) Related to the mission, (7) Arranged by the manager, (8) Systematic arrangement with the strategic implementation (M) of the Wahab concept (2001), namely: (1) Performed by individuals, (2) To achieve goals (3) Objectives based on policy decisions on Managerial Performance (Y) with evaluation dimensions (indicators: something achieved, work unity, as a target, high productivity, overall results, activity results), coordination (indicators: meeting requirements, individual contribution, obeying the law, something that has been agreed upon), amounting to 0.323 or $32.3 \%$ and not significant. This means that for every increase in the strategic planning variable by 1 unit, the strategic implementation variable will decrease by 0.226 units, assuming the other variables are fixed.

\section{CONCLUSION}

\section{The theoretical implications of this research}

The existence of other influences outside the model can be attributed to the Background Theory according to the thought of Karl Marx (1818-1883) which divides society into two classes, namely the bourgeoisie (owners of capital) and proletariat (workers) and Max Weber (1864-1920) divides society into two groups, namely the super-ordinates (parties who have power) and sub-ordinates (managers), Grand Theory according to George Simmel (18581918), Lewis A. Coser (1913-2003), and Ralf Dahrendorf (1929-2009) regarding conflict 
theory with different thoughts, and Middle Range Theory according to Jensen-Meckling's (1976) thinking about Agency Theory, where this theory explains the conflict that occurs between agents (capital managers or management) and owners of capital or shareholders ( principal).

This research has two theories as Background Theory, namely Karl Marx (18181883) and Max Weber (1864-1920) regarding conflict theory. This research supports the explanation of Karl Marx and Max Weber. According to Karl Marx, society is divided into two groups, namely the bourgeoisie (owners of capital) and the proletariat (workers). In this day and age, the bourgeoisie can be likened to the owners of companies and the proletariat as the people (managers) who work for the owners of companies. Company owners always demand managers to produce good performance so that company goals can be achieved. Meanwhile, Weber's thought states that society is divided into two groups, namely the super-ordinate (those who have power) and the sub-ordinate (the managers). Weber's thinking is basically the same as that of Marx, where managers cannot fight the demands and power of the company owners.

In addition, this research is associated with the Grand Theory of George Simmel (1858-1918), Lewis A. Coser (1913-2003), and Ralf Dahrendorf (1929-2009). George Simmel has 3 theories, namely: (1) interaction theory, where company parties need interaction to disclose information and changes, (2) the philosophy of money theory, where all humans need money and sometimes money is more important than meaning or role. humans themselves, (3) conflict theory, in which every level of society must experience conflict due to various factors, one of which is the greedy attitude of humans to have money. Lewis.A.Coser has ideas that are not much different from Simmel's regarding conflict theory. Ralf Dahrendorf has other thoughts about conflict, where according to him, humans do not always experience continuous conflict, but humans can establish good cooperation to achieve company goals.

This research is also associated with Jensen-Meckling's (1976) Middle Range Theory regarding Agency Theory, where this theory explains the conflict that occurs between an agent (capital manager or management) and the owner of capital or shareholders (principal). The owner wants to get high dividends, interest and profits; while management wants to obtain welfare from the company through wages, salaries, bonuses, compensation, and high positions. Management is a shareholder agent in the company. Shareholders hope that agents can act on their behalf and delegate authority to the agent. In order to carry out its functions properly, management must be given adequate intensive supervision.

\section{Conclusion}

The results of this study support the concept of External Factors $\left(\mathrm{X}_{1}\right)$ according to Wood et al. (1993: 74), David (2005: 47), on concept of Internal Factors $\left(X_{2}\right)$ is in accordance with Glueck and Jaunch (2000: 162), Agus Sunyoto (2005: 67), Sugihartono, et al. (2007: 7677), Fred R. David (2009: 47); the concept of Strategic Planning $\left(X_{3}\right)$, Dovel et al. (1993: 245), James Stoner and R. Edward Freeman (1994: 204), Abe (2001, 43); the concept of Strategic Implementation (M) is in accordance with Schermerhorn (1996: 172), Hitt, Ireland, and Hoskisson (2000: 188). The results of this study support: (a) Background Theory, namely Karl Marx (1818-1883) and Max Weber (1864-1920); (b) Grand Theory, namely George Simmel (1858-1918), Lewis A. Coser (1913-2003), Ralf Dahrendorf (1929-2009); (c) Middle Range Theory, namely Jensen Meckling (1976).

\section{REFERENCES}


Bernardin, H. John dan Joyce, E.A Russel. (2002). Human Resource Management. Singapore: McGraw Hill, Inc.

Coser, Lewis. (1956). The function of social conflict. New York Free Press. . (1967). Continuities in the study of social conflict. New York Free Press.

Dahrendorf, Ralf. (1959). Class and class conflict in industrial society. Calif: Stanford University Press.

Daito, Apollo. (2007). Petunjuk penulisan skripsi, tesis, disertasi. Jakarta: Fakultas Ekonomi.

_ ( 2011). Pencarian ilmu melalui pendekatan ontologi, epistemologi, aksiologi. Edisi

Pertama. Jakarta: Mitra Wacana Media.

David, Fred R. (2009). Manajemen Strategis. Edisi Sepuluh. Jakarta: Penerbit Salemba Empat. .(2009). Manajemen Strategis. Jakarta: Penerbit Salemba Empat.

Dessler, Gary. (2008). Human Resource Management (International Edition, 10 th ed). New Jersey: Pearson Education International.

Donnelly, James H., Gibson, James L., and Ivancevich, John. (1993). Fundamental of Management. Texas: Bussiness Publication.

Freeman, R. Edward and Stoner, James Af (1994). Strategic management: a stockholder approach. England: Cambridge University Press.

Glack dan Jauch. (2000). Strategic management and corporate policies. $3^{\text {rd }}$ ed. New York: McGraw Hill.

Gomes, Faustino, Cardoso. (2003). Manajemen Sumber Daya Manusia. Andi. Yogyakarta: Offset Yogyakarta.

Gujarati, Domodar. (2003). Basic econometrics. $2^{\text {nd }}$ ed. New York: McGraw Hill International Edition.

Hitt, Michael A., R. Duane Ireland, and Robert E. Hoskinson. (2000). Strategic Management, Competitiveness and Globalization. USA: Thomson International Student Edition USA.

Kaesler, Dirk (1989). Max Weber: An Introduction to His Life and Work. University of Chicago Press.Koontz, Harold and O'Donnell, Cyril. (2009). Principles of management: an analysis of managerial functions. New York: McGraw Hill.

Mahoney, T.A., Jerdee, T.H., and Carroll, S.J. (1963),. Management accounting on managerial performance. New York: McGraw Hill.

Moore, J.F. (1995) ., The Death of Competition, Leadership \& Strategy in the Age of Business Ecosystem. Harper Business.

Newstrom, John W. and Davis, Keith E. (2007). Organizational behaviour: human behaviour at work. $11^{\text {th }}$ ed. New York: McGraw Hill.

Pearce II, John. A and Richard B. Robinson. (2003)., Strategic Management: Formulation, Implementation and Control. Hill International Edition. USA: (P and R).

Porter, Michael E. (1980). Competitive strategy: techniques for analyzing industries and competitors. New York Press.

. (1985). Competitive advantage: creating and sustaining superior performance. New York Free Press (2008). Competitive Advantage : creating and sustaining superior performance. New York Free Press.

Robbins, Stephen P. (2006). Organizational behaviour: concepts, controversies, applications. $6^{\text {th }}$ ed. New Jersey: Pearson Prentice Hall.

, and Judge, Timothy A. (2008). Organizational behavior. $12^{\text {th }}$ ed. New Jersey: Pearson Prentice Hall. 
Robinson, Richard B. and Pearce, John A. (2011). Strategic management: formulation, implementation, control. $12^{\text {th }}$ ed. New Jersey: Pearson Prentice Hall.

Schermerhorn, John R. (1996). Management. $5^{\text {th }}$ ed. America: John Wiley and Sons, Inc.

Sekaran, Uma. (2002). Research methods for business. University at Corbandale.

Sorkin, L. Donna, Ferris B. Nancy, and Hudak J. (2001). Strategies for Cities and Counties: A Strategic Planning Guide. USA: Public Technology, Inc.

Turner, J. H. (1998). The Structure of Sociological Theory (sixth edition). Belmont CA: Wadsworth Publishing Company.

Vroom, V. H. \& Jago, A. G. (1988).The new leadership:Managing participation in organizations. Englewood Cliffs, N. J: Prentice Hall.

Whellen, Thomas L. and Hunger, J. David. (2007). Strategic management and business policy: achieving sustainability. $12^{\text {th }}$ ed. New Jersey: Pearson Prentice Hall. . (2012). Strategic management and business policy: achieving sustainability. $13^{\text {th }}$ ed. New Jersey: Pearson Prentice Hall.

Williams, Richard R. (2002). Managing employee performance: design and implementation in organizations. London: Thomson Learning.

Wood, J.M., Wallace, J., Zeffane, Schermerhorn, Hunt, Osborn. (1993) Organizational Behaviour an Asia-Pacific Perspective. Singapore: John Wiley \& Sons.

. (1998) Organizational Behaviour an Asia-Pacific Perspective. Singapore: John Wiley \& Sons.

Journals:

Arasa, Robert dan K'Obonyo, Peter .(2012). The Relationship between Strategic Planning and Firm Performance. International Journal of Humanities and Social Science, Vol. 2, No. 22, November 2012, hlm. 201-213.

Aryani, Dwi, dan Rosinta, Febrina. (2010) Pengaruh Kualitas Layanan terhadap Kepuasan Pelanggan dalam Membentuk Loyalitas Pelanggan. Bisnis \& Birokrasi, Jurnal Ilmu Administrasi dan Organisasi, Vol. 17, No. 2, Mei-Agus 2010, hlm. 114-126.

Darya, I Gusti Putu. (2012). Pengaruh ketidakpastian lingkungan dan karakteristik kewirausahaan terhadap kinerja manajerial. Jurnal Inovasi dan Kewirausahaan. Vol 1. No. (1). hal. 65-78.

Fibrianti, Diana dan Riharjo, Ikhsan Budi .(2013). Pengaruh Partisisipasi Penganggaran. Desentralisasi, Komitmen Organisasi, dan Ketidakpastian Lingkungan Terhadap Kinerja Manajerial. Jurnal Ilmu dan Riset Akuntansi Vol 1, No 1, Januari 2013, hlm. 108-121.

Hastuti, Sri dan Wahyuningsari, Hanita. (2010). Pengaruh partisipasi penganggaran dan keadilan prosedural terhadap kinerja manajerial. Jurnal Riset Ekonomi dan Bisnis. Vol 10. No. (1). hal. 1-8.

Hidayat, Rachmad dan Budianto, Hairil. (2009). Pengaruh faktor lingkungan terhadap kinerja manajerial. Jurnal Ilmiah Semesta Teknika. Vol 12. No. (1). hal. 10-20.

Jensen, Michael and Meckling, William. (1976). Theory of firms: managerial behavior, agency cost, and ownership structure. Journal of Financial Economics. Vol 3. p. 98-160.

Mason, E.S. (1953). Price and production policies of large scale enterprises. American Economic Review. Vol 29. p. 61-74.

Musyarofah, Siti. (2004). Pengaruh penggunaan anggaran dan gaya manajemen terhadap hubungan antara perubahan stratejik dan kinerja organisasi.JAAI.Vol 8. No.1. 
Nuswandari, Cahyani. (2009). Pengaruh Corporate Governance Perception Index Terhadap Kinerja Perusahaan pada Perusahaan yang Terdaftar di Bursa Efek Jakarta. Jurnal Bisnis dan Ekonomi (JBE) Vol.16, No.2, September 2009, Hal. 70 - 84.

Porter, Michael E. (1981). The contributions of industrial organization to strategic management. Academy of Management Review. Vol 6. No. (4). p. 609-620.

R.A.Supriyono. (2005). Pengaruh Variabel Perantara Kecukupan Anggaran dan Partisipasi Penganggaran terhadap Hubungan Antara Komitmen Organisasi dan Kinerja Manajerial di Indonesia. Jurnal Ekonomi Perusahaan. Vol. 12. No. 1 pp 13-29

Tewal, Bernhard. (2010). Pengaruh strategi bersaing dan inovasi terhadap kinerja manajerial. Jurnal Aplikasi Manajemen. Vol 8. No. (2). hal. 464-470.

Wibowa, Edi (2006). Ketidakpastian Lingkungan Sebagai Variabel Pemoderasi Hubungan Antara Penyusunan Anggaran Partisipasif dengan Kinerja Manajerial. Jurnal Akuntansi dan Sistem Teknologi Informasi Vol. 5, No. 1, April 2006: 39 - 51. 